\title{
IMPLEMENTASI TEAM GAMES TOURNAMENT (TGT) DALAM MENINGKATKAN KERJASAMA DAN HASIL BELAJAR IPA
}

\section{THE IMPLEMENTATION OF TEAM GAMES TOURNAMENT LEARNING (TGT) IN IMPROVING THE COOPERATION AND SCIENCE LEARNING OUTCOMES}

\author{
Noni Triowathi dan Astuti Wijayanti \\ Program Studi Pendidikan IPA FKIPUniversitas Sarjanawiyata Tamansiswa, Yogyakarta, Indonesia \\ Email:astuti.wijayanti@ustjogja.ac.id
}

Diterima: 20 Juli 2018. Disetujui: 24 September 2018. Dipublikasikan: 25 September 2018

\begin{abstract}
Abstrak: Penelitian ini bertujuan untuk mengetahui implementasi pembelajaran Team Games Tournament (TGT) dalam meningkatkan kerjasama dan hasil belajar IPA siswa kelas VIII SMPN 12 Yogyakarta. Teknik pengumpulan data menggunakan tes, observasi, angket, dan dokumentasi. Teknik analisis data dilakukan secara kualitatif dan kuantitatif. Instrumen tes hasil belajar IPA dan kerjasama siswa di uji validitas dan relialibilitasnya. Hasil penelitian menunjukkan bahwa rata-rata persentase kerjasama siswa meningkat sebesar 7,09\% dari siklus pertama sebesar 75,08 \% meningkat menjadi 82,17\% pada siklus kedua. Rata-rata hasil belajar IPA siswa meningkat sebesar 9,28 \% dari siklus I 65,30\% meningkat menjadi 75,1\% pada siklus kedua.
\end{abstract}

Kata Kunci: Team games tournament, Hasil belajar IPA, Kerjasama siswa

\begin{abstract}
This study aims to determine the implementation of team games tournament learning (TGT) in improving the cooperation and science learning outcomes of class VIII at SMPN 12 Yogyakarta. This type of research is a classroom action research. Techniques of collecting data using tests, observations, questionnaires, and documentation. Data analysis technique is done qualitatively and quantitatively. Instrument test of science learning result and student cooperation invalidity and reliability test. The results showed that the average percentage of student cooperation increased by $7.09 \%$ from the first cycle by $75.08 \%$ to $82.17 \%$ increase in the second cycle. The average of science learning outcomes of students increased by $9.28 \%$ from cycle I $65.30 \%$ increased to $75.1 \%$ in the second cycle.
\end{abstract}

Keywords: Team games tournament, IPA study result, student cooperation.

\section{PENDAHULUAN}

Pendidikan memainkan peranan penting
dalam kehidupan dan kemajuan umat manusia.Pendidikan saat ini merupakan salah satu kebutuhan pokok yang harus dipenuhi oleh setiap insan.Program pendidikan tidak hanya menekankan pada aspek pengetahuan (cognitive) saja tetapi juga menekankan pada pembinaan sikap dan pengembangan keterampilan peserta didik [1]. Melalui pendidikan, manusia diharapkan dapat meningkatkan kualitas hidupnya sehingga menjadi bangsa yang maju.

Pembelajaran di dalam kelas merupakan bagian yang sangat penting dari proses pendidikan. Jika pelaksanaan pembelajaran di kelas bermutu akan menghasilkan output yang berkualitas. Guru memiliki peran yang sangat besar dalam mengorganisasikan kelas sebagai bagian dari proses pembelajaran dan siswa sebagai subyek yang sedang belajar. Kemampuan guru dalam mengemas suatu rancangan pembelajaran yang bermutu tentu diawali dari persiapan mengajar yang matang [2].
Berhasil tidaknya suatu tujuan pendidikan bergantung pada bagaimana proses belajar mengajar dirancang dan disajikan. Guru dituntut untuk kreatif dan inovatif dalam pemilihan model pembelajaran. Proses pembelajaran akan berjalan dengan baik jika ada motivasi dan penyampaian materi yang jelas dari guru [3]. Keberhasilan pembelajaran di sekolah sangat dipengaruhi oleh beberapa faktor yaitu siswa, kurikulum, guru, sarana dan prasarana serta faktor lingkungan. Apabila faktor-faktor tersebut dapat terpenuhi, sudah tentu akan memperlancar proses pembelajaran yang akan menunjang pencapaian hasil belajar maksimal yang akhirnya dapat meningkatkan kualitas pembelajaran [4].

Untuk meningkatkan kerjasama dan hasil belajar IPA siswa, guru dapat menggunakan berbagai macam model pembelajaran. Model yang bersifat merangsang siswa untuk belajar mandiri, kreatif, dan lebih aktif dalam mengikutipembelajaran. Didalam pembelajaran kooperatif tidak hanya mempelajari materi saja, namun siswa juga mempelajari keterampilanketerampilan khusus yang disebut keterampilan kooperatif [5]. Pembelajaran kooperatif adalah model pembelajaran yang mengutamakan 
kerjasama untuk mencapai tujuan pembelajaran [611].

Berdasarkan hasil observasi pada mata pelajaran IPA kelas VIII A di SMP Negeri 12 Yogyakarta, terdapat permasalahan antara lain; kurangnya keaktifan siswa dan kurangnya inovasi dalam pembelajaran, pembelajaran IPA masih berorientasi pada guru, siswa tidak diarahkan untuk berfikir kreatif dan menguasai konsep berdasarkan penemuan-penemuan di alam sekitar. Hasil ratarata nilai ulangan siswa kurang maksimal pada mata pelajaran IPA tahun pelajaran 2017/2018 dengan nilai rata-rata 71,21 dari nilai kriteria ketuntasan minimal (KKM) yang ditentukan terbesar77. Perolehan nilai rata-rata kelas yang rendah dipengaruhi pada ketidaktertarikan siswa untuk belajar IPA. Pembelajaran IPA yang dilakukan masih secara konvensional, yaitu guru menyampaikan materi pelajaran dengan ceramah dan siswa mencatat pada buku catatan (taceher center). Diperlukan suatu usaha agar pembelajaran lebih menarik, bermakna, menyenangkan, maupun meningkatkan kemampuan kerjasama siswa dan memudahkan siswa dalam belajar.

"Pembelajaran sering dipahami dengan proses belajar mengajar di mana didalamnya ada interaksi guru dan siswa dan antar sesama siswa untuk mencapai suatu tujuan yaitu terjadinya perubahan sikap dan tingkah laku siswa" [12]. Hasil belajar adalah kemampuan-kemampuan yang dimiliki siswasetelah ia menerima pengalaman belajarnya [13].

Model pembelajaran adalah suatu perencanaan atau suatu pola yang digunakan dalam pembelajaran di kelas untuk mengarahkan peserta didik dalam membantu mencapai tujuan pembelajaran [14]. Slavin [15] mengemukakan Teams Games Tournament (TGT) adalah model pembelajaran kooperatif menggunakan turnamen akademik dan menggunakan kuis-kuis, dimana para siswa berlomba sebagai wakil tim mereka dengan anggota tim lain yang kinerja akademik sebelumnya setara seperti mereka. Kerjasama dalam konteks pembelajaran yang melibatkan siswa. Karakteristik TGT yaitu siswa belajar dalam kelompok kecil dimana dalam proses pembelajaran terdapat games tournament yang nantinya akan ada penghargaan kelompok [16]. Aktivitas belajar dengan permainan yang dirancang dalam pembelajaran kooperatif model TGT memungkinkan siswa dapat belajar lebih rileks disamping menumbuhkan tanggung jawab, percaya diri, menghargai sesama, disiplin, kompetitif, sportif, kerja sama dan keterlibatan belajar seluruh siswa. Huda [12] menjelaskan lebih rinci yaitu, ketika siswa bekerja sama untuk menyelesaikan suatu tugas kelompok, mereka memberikan dorongan, anjuran, dan informasi pada teman sekelompoknya yang membutuhkan bantuan.

\section{METODE PENELITIAN}

Penelitian ini merupakan penelitian tindakan kelas (PTK).Penelitian ini yang dilaksanakan di SMPN 12 Yogyakarta. PTK ini bertujuan memperbaiki pembelajaran dikelas [17]. Subjek dalam penelitain ini adalah siswa kelas VIII A SMPN 12 Yogyakarta pada semester gasal pada tahun pelajaran 2017/2018.Teknik pengumpulan data yang dilakukan pada penelitian ini adalah observasi, dokumentasi, angket dan tes. Dokumentasi adalah teknik penelitian yang digunakan untuk mencari data mengenai hal-hal atau variabel yang berupa buku-buku, majalah, dokumen, peraturan-peraturan, notulen rapat, catatan harian, dan sebagainya [18]. Angket/kuisioner merupakan metode pengumpulan data yang dilakukan dengan cara memberikan seperangkat pernyataan atau pernyaan tertulis kepada responden untuk diberikan sesuai dengan permintaan pengguna [19].

Menurut Arikunto [18] tes merupakan alat atau prosedur yang digunakan untuk atau mengukur sesuatu dalam dengan aturan-aturan yang sudah ditentukan. Uji coba instrumen dalam penelitian ini adalah uji validitas dan uji reliabilitas. Pengujian validitasmenggunakan rumus korelasi product moment [18]. Uji reliabilitas menggunakan KR-20 diperoleh $r_{t t}=0.743$. Teknik analisis data adalah kuantitatif dan kualitatif.

\section{HASIL DAN PEMBAHASAN}

Penelitian tindakan kelas ini dilakukan sebanyak 2 siklus.Siklus 1 terdiri dari 5 pertemuan dan siklus II sebanyak 3 pertemuan.Penelitian tindakan kelas ini, dilaksanakan dengan peneliti bertindak sebagai guru.Setiap siklus terdiri dari 4 tahap yaitu perencanan, tindakan, pengamatan dan refleksi.

Siklus 1 terdiri dari 5 pertemuan. Pertemuan ke 1 dan 3 menyampaikan pembelajaran dengan STAD sebagai upaya meningkatkan kekompakan kelompok asal atau heterogen dengan materi mengidentifikasi jenis-jenis bahan makanan serta kandungan bahan makanan dalam kehidupan sehari-hari melalui uji bahan makanan. Pada pertemuan ke 2 dan 4, guru membagi siswa ke dalam kelompok homogen dan melakukan TGT. Pertemuan ke 5 yaitu tes evaluasi, penjabaran tahapan siklus 1 sebagai berikut.

Perencanaan (Planning) pada siklus I berupa perencanaan tindakan yang dilakukan dalam penelitian ini antara lain sebagai berikut: 1)Peneliti menyusunrencana pelaksanaan pembelajaran (RPP) dengan langkah-langkah pembelajaran TGT, 2) Peneliti menyusun dan menyiapkan instrumen penelitian, berupa lembar kerja siswa (LKS), tes, dan lembar observasi aktivitas guru dan siswa, serta angket kerjasama siswa.

Pelaksanaan tindakan siklus 1 pada pembelajaran IPA dengan menggunakan model pembelajaran kooperatif tipe TGT telah 
dilaksanakan sesuai dengan rencana tindakan yang dibuat. Secara umum dilaksanakan sebagai berikut: Guru membagi siswa dalam sebuah kelompok homogen terdiri dari empat sampai enam orang siswa yang mempunyai kemampuan yang berbeda-beda. Siswa dalam 1 kelas beranggotakan 34 orang dan guru membagi siswa kedalam kelompok heterogen menjadi 5 kelompok masing-masing kelompok berisi 6 anggota. Siswa berpindah kekelompok homogen yang telah dibagi dan ada juga siswa yang tidak mau berpindah kekelompok yang telah dibagi oleh guru. Guru belum memberikan nama kelompok.

Guru membagi siswa kedalam meja-meja turnamen yang telah guru siapkan. Guru bersama dengan siswa bersama-sama menyiapkan meja turnamen, meja turnamen yang telah disiapkan ada 4 meja turnamen. Siswa ada yang membantu guru menyediakan meja turnamen dan ada siswa yang telah duduk di kursi dan meja yang telah disediakan.Pada waktu menyiapkan suasana menjadi gaduh.

Guru membagi kartu soal dan kartu jawaban ketiap meja-meja turnamen.Guru membagikan kartu soal dan jawaban yang mempunyai warna yang berbeda kartu soal berwarna putih dan kartu jawaban ber warna biru masing-masing kartu mempunyai nomor dibelakang kartu yang sudah disiapkan. Masingmasing meja turnamen mempunyai kartu soal dan kartu jawaban yang sama dan jumlah soal yang ada di kartu soal masing-masing adalah 30 soal. Siswa masih ada yang kurang mengerti/ keliru dengan warna kartu soal dan kartu jawaban.

Setelah guru membagi kartu soal dan kartu jawaban selanjutnya guru menjelaskan aturan pertandingan atau turnamen yang telah dibagi diselembaran kertas yang telah dibagi dimasingmasing kelompok.Pada saat guru menjelaskan guru memilih salah satu kelompok untuk mensimulasikan dalam aturan pertandingan. Guru sambil menjelaskan aturan pertandingan disetiap kelompok diminta untuk memperhatikan pada saat guru menjelaskan aturan pertandingan. Pada saat guru menjelaskan aturan permainan di depan masih ada siswa yang tidak mendengarkan penjelasan guru tentang aturan pertandingan yang akan dilaksanakan.

Guru memberikan kesempatan untuk setiap kelompok turnamen untuk melakukan permainan. Pada saat melakukan turnamen guru menghampiri masing-masing meja turnamen yang sedang dilaksanakan.Pada saat pelaksanaan permainan ada siswa yang masih mengangu teman di meja turnamen disebelah. Siswa masih ada yang belum mengerti cara perputaran permainan.

Setelah pertandingan ditiap meja-meja turnamen selesai, guru meminta siswa untuk kembali ke kelompok asalnya. Guru meminta siswa untuk mengumpulkan kartu soal dan kartu jawaban yang sudah dijawab dan kartu soal dan kartu jawab yang belum dijawab oleh kelompok. Siswa kembali ramai pada saat diminta guru untuk kembali kekelompoknya masing-masing. Setelah permainan selesai guru memberikan skor/poin sesuai dengan jumlah kartu soal dan kartu jawaban yang berhasil dijawab.Sementara siswa masih ada yang sibuk dengan temannya sendiri.Setelah guru menyelesaikan perhitungan skor/poin dari tiap kelompok, guru belum memberikan penghargaan kepada kelompok yang memperoleh skor/poin tertinggi. Guru memberikan informasi kepada siswa agar siswa belajar lagi dan saling membantu siswa yang masih belum mengerti dengan pelajaran.

Hasil observasi aktivitas guru pada siklus I masih terdapat kekurangan yaitu; 1) Guru belum memberi nama kelompok turnamen, 2) Guru belum menyiapkan meja turnamen, 3) Guru memberikan kertas yang berisi aturan pertandingan dan simulasi aturan turnamen, 4) Guru belum menghampiri setiap meja turnamen, 5) Guru kurang menguasai kelas pada waktu permainan perkelompok sedang berjalan, 6) Guru belum meminta siswa kembali ke kelompoknya dan belum meminta kartu soal dan kartu jawaban yang telah dijawab oleh siswa dikumpulkan, 7) Guru belum memberikan skor/poin kepada tiap kartu soal dan kartu jawaban yang telah dijawab, 8) Guru belum memberikan penghargaan kelompok yang mendapatkan skor/poin yang tertinggi, guru menginformasikan agar siswa bisa membantu teman lainnya untuk belajar lagi.

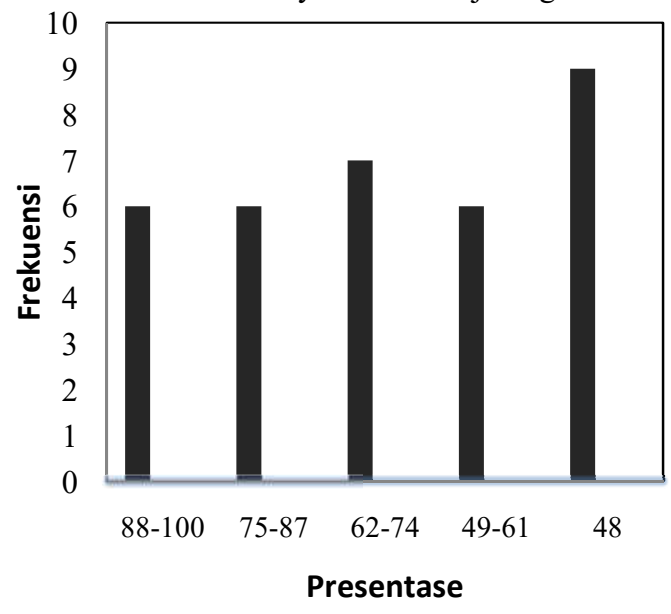

Gambar 1. Hasil Belajar IPA Siklus I. Keterangan Gambar 1 adalah 1) Siswa tidak langsung membentuk kelompok yang telah guru tuliskan nama-nama siswa, 2) Siswa menempati meja-meja turnamen yang telah di siapkan bersama dengan guru, 3) Siswa masih ada yang tidak menaati peraturan, 4) Siswa dalam pelaksanaan permainan masih ada yang menggangu temanya, 5) Siswa masih ada yang bertanya saat guru mengunjungi meja turnamen, 6) Siswa masih ada yang tidak kembali kekelompok asal, 7) Siswa masih ada yang 
tidak mendengarkan guru saat menjelaskan permainan didepan, 8) Siswa di masing-masing meja turnamen melaksanakan turnamen dan masih ada yang menggangu teman, 9) Siswa sedikit gaduh saat dibacakan skor/poin perkelompoknya, Semua siswa akan diberikan penghargan.

Hasil posttes siswa dengan hasil belajar siswa pada siklus Idapat dilihat pada Gambar 1. Gambar 1 mengambarkan rata-rata nilai siswa pada siklus I 65,30 pada siklus I jumlah siswa yang belum tuntas mencapai 12 siswa, jumlah siswa yang mencapai KKM sebanyak 22 siswa. Guru memotivasi siswa agar terus meningkatkan hasil belajar IPA siswa. Berdasarkan hasil kerjasama siswa pada siklus I rata-rata kerjasama siswa mencapai $75,08 \%$. Hasil kerjasama belajar IPA siswa pada siklus I ditampilkan pada gambar 2.

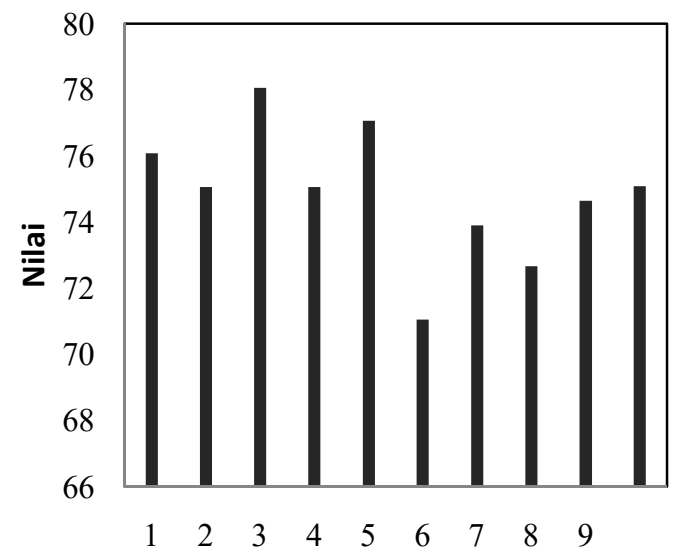

Gambar 2. Persentase kerjasama siswa siklus I. Keterangan gambar 2 adalah 1) Mengikuti aturan, (2) Membantu teman yang mengalami kesulitan,(3) Ingin semua teman bermain dan berhasil,(4) Memotivasi orang lain,(5) Berpartisipasi dalam menyelesaikan games, (6) Mengendalikan tempramen, (7) Menghargai hak orang lain, (8) Kerjasama meraih tujuan, (9) Menerima pendapat orang lain.

Gambar 2 meningkat tidaknya persentase kerjasama siswa siklus I terutama indikator nomor 3 lebih senang bekerjasama $(78.06 \%)$, pada indikator 6 tidak bisa mengendalikan tempramen(71.05\%), dan pada indikator 7 lebih menghargai orang lain (73.19). Pada indikator 7 dan 9 dimana masih ada siswa yang menghargai pendapat hak orang lain dan menerima pendapat harus lebih ditingkatkan lagi.

Dari hasil refleksi (evaluasi pelaksanaan tindakan dan hasil observasi) siklus I disimpulkan bahwa pembelajaran IPA dengan menggunakan model pembelajaran kooperatif tipe TGT sudah berjalan dengan prosedur yang telah direncanakan. Namun ada beberapa masalah yang perlu ditindaklanjuti adalah sebagai berikut: (1) Guru membagi semua siswa ke dalam kelompok turnamen dengan dituliskan di papan tulis dan diberinama kelompok, (2) Guru sudah menyediakan/menata meja turnamen yang akan digunakan, (3) Guru membagi kartu soal dan kartu jawaban yang telah dituliskan nomor yang sama dengan jumlah yang sama, (4) Guru menjelaskan aturan turnamen yang akan dilaksanakan dengan keras, jelas dan tegas, (5)Guru mengulang kembali simulasi aturan TGT, (6) Guru memberikan batasan waktu untuk melaksanakan turnamen, (7) Guru berkeliling menghampiri ke setiap meja turnamen yang sedang melaksanakan turnamen, (8) Guru meminta siswa untuk kembali kekelompok asal setelah melaksanakan turnamen, (9)Guru memberikan skor/poin kepada tiap kelompok sesuai dengan jumlah kartu soal dan kartu jawaban yang telah dijawab tiap kelompok, (10) Guru memberikan penghargaan kepada kelompok yang mendapatkan skor/poin yang tinggi.

\section{Siklus II}

Pelakanaan penelitian untuk Siklus II terdiri dari 5 kali pertemuan. Pertemuan ke 1 dan 3 menyampaikan pembelajaran dengan STAD sebagai upaya meningkatkan kekompakan kelompok asal/homogen dengan materi menjelaskan efek penggunaan bahan adiktif bagi kesehatan. Pada pertemuan ke 2 dan 4, guru membagi siswa ke dalam kelompok homogen dan melakukan TGT pada siklus II. Pertemuan ke 5 yaitu tes evaluasi.

Perencanaan pelaksanaan pada siklus II pada dasarnya sama dengan siklus I. Berdasarkan refleksi yang dilakukan terhadap siklus I, ada beberapa permasalahan yang harus diselesaikan sehingga pada siklus II dapat diperbaiki agar pembelajaran dapat berlangsung lebih optimal dan diharapkan akan terjadi peningkatan kembali sehingga indikator keberhasilan dapat dicapai dengan baik.

Pelaksanaan Tindakan PTK siklus II pada pembelajaran IPA dengan menggunakan model pembelajaran kooperatif tipe TGT telah dilaksanakan sesuai dengan rencana tindakan yang dibuat. Pada siklus II, kegiatan pembelajaran dilakukan dalam lima kali pertemuan. Pertemuan pertama dilakukan pada hari Kamis, 23 November 2017. Guru mengajar materi zat adiktif dan psikotropika. Pertemuan kedua dilaksanakan pada hari selasa, 28 November 2017. Pertemuan ketiga dilaksanakan tanggal 30 November 2017. Guru mengajarkan tentang efek samping dari bahan adiktif tehadap kesehatan. Pertemuan kedua guru mengajar materi IPA. Guru melaksanakan tindakan sesuai dengan rencana pembelajaran yang telah disusun. Deskripsi pelaksanaan dan pembelajaran IPA dengan menggunakan model pembelajaran kooperatif tipe TGT di kelas VIII A SMP Negeri 12 Yogyakarta sebagai berikut. 
Pembelajaran dimulai, guru dan kolaborator mengucapkan salam kepada siswa, berdoa serta mengecek kehadiran siswa. Sebelum memulai pelajaran, guru terlebih dahulu menjelaskan tujuan pembelajaran, apersepsi dan motivasi siswa. Guru menjelaskan cakupan materi yang akan dipelajari pada pertemuan siklus II yaitu materi yang diajarkan mendeskripsikan materi IPA.

Guru membagi siswa menjadi beberapa kelompok yang beranggotakan 5-6 orang secara homogen. Guru meminta siswa untuk berkumpul dengan kelompok sesuai dengan nama-nama yang telah dibagikan/dituliskan oleh guru dipapan tulis. Semua siswa sudah mulai mengikuti semua perintah guru saat pembagian kelompok dimulai. Guru sudah dapat mengkondisikan siswa dalam kelompok, karena pada saat pembagian kelompok suasana kelas teratur dan siswa sudah dapat menempatkan diri pada tugasnya masing-masing ketika perpindahan sesuai dengan kelompoknya.

Kelompok sudah terbentuk, siswa sudah bersiap-siap berkumpul dengan teman kelompoknya, sesuai dengan arahan dari guru. Guru sudah mampu mengendalikan siswa dalam pembagian kelompok. Suasana kelas tenang dan tidak gaduh karena semua tertata secara teratur dan pada kelompok masing-masing. Mereka sudah mau berkelompok dengan kelompok yang dibentuk guru. Guru sudah dapat mengkondisikan siswa di dalam kelas dalam pembagian kelompok.

Guru membagi siswa ke dalam meja-meja turnamen yang telah guru siapkan. Gurusudah menyiapkan meja turnamen, meja turnamen yang telah disiapkan ada 4 meja turnamen. Siswa langsung duduk ke meja turnamen masing-masing. Guru membagi kartu soal dan kartu jawaban ke tiap meja-meja turnamen.

Guru membagikan kartu soal dan jawaban yang mempunyai warna yang berbeda kartu soal berwarna putih dan kartu jawaban berwarna biru masing-masing kartu mempunyai nomor di belakang kartu yang sudah disiapkan. Masingmasing meja turnamen mempunyai kartu soal dan kartu jawaban yang sama dan jumlah soal yang ada di kartu soal masing-masing adalah 30 soal.

Setelah guru membagi kartu soal dan kartu jawaban selanjutnya guru menjelaskan aturan pertandingan atau turnamen yang telah dibagi di selembaran kertas yang telah dibagi di masingmasing kelompok. Pada saat guru menjelaskan guru memilih salah satu kelompok untuk mensimulasikan dalam aturan pertandingan. Guru sambil menjelaskan aturan pertandingan di setiap kelompok diminta untuk memperhatikan pada saat guru menjelaskan aturan pertandingan. Guru menjelaskan aturan permainan yang akan dilaksanakan dengan keras, jelas dan tegas.

Guru memberikan kesempatan untuk setiap kelompok turnamen untuk melakukan permainan. Pada saat melakukan turnamen guru menghampiri masing-masing meja turnamen yang sedang dilaksanakan. Siswa sudah mengerti cara perputaran permainan.

Setelah pertandingan di tiap meja-meja turnamen selesai, guru meminta siswa untuk kembali ke kelompok asalnya. Guru meminta siswa untuk mengumpulkan kartu soal dan kartu jawaban yang sudah dijawab dan kartu soal dan kartu jawab yang belum dijawab oleh kelompok. Setelah permainan selesai guru memberikan skor/poin sesuai dengan jumlah kartu soal dan kartu jawaban yang berhasil dijawab.Setelah guru menyelesaikan perhitungan skor/poin dari tiap kelompok. Guru memberikan penghargaan kepada kelompok yang memperoleh skor/poin tertinggi.

Guru bersama siswa menyimpulkan hasil diskusi dan mengklarifikasi bila ada yang salah dari pemahaman siswa. Guru menegaskan siswa untuk mempelajari kembali materi yang sudah dipelajari dan guru mengumumkan bahwa pada pertemuan selanjutnya akan ada tes evaluasi.

Tes evaluasi siklus II meliputi materi yang zata diktif dan psikotropika. Tes evaluasi yang diberikan berupa tes obyektif pilihan ganda berjumlah 30 butir soal dengan alternatif 4 pilihan ganda. Siswa diberikan waktu selama 40 menit untuk mengerjakan. Pada siklus II siswa tampak lebih siap dan tenang dalam menyelesaikan soal tes tersebut. Guru memberikan kesempatan kepada siswa untuk mengecek kembali jawaban bagi yang sudah selesai dan meminta siswa untuk mengumpulkan jawabannya. Setelah selesai mengerjakan tes evaluasi, guru memberikan angket kerjasama siswa. Guru memberikan waktu 10 menit kepada siswa untuk mengisi angket. Guru memberikan penghargaan bagi kelompok terbaik dalam bekerjasama dan dalam mengerjakan tugas dengan baik.

Hasil pengamatan/observasi siklus II oleh kolaborator dan catatan hasil observasi menunjukkan bahwa guru telah melaksanakan prosedur atau langkah-langkah pembelajaran IPA dengan model pembelajaran kooperatif tipe TGT yang direncanakan. Perbaikan-perbaikan yang telah direncanakan telah dilaksanakan sebaik-baiknya. Pembimbingan pada kelompok-kelompok ditingkatkan, mengamati setiap kerja kelompok, diskusi yang dilakukan masing-masing kelompok.

Hasil observasi aktivitas siswa pada siklus II di atas, siswa sudah melaksanakan semua aspek yang diamati ketika mengerjakan dengan model pembelajaran kooperatif tipe TGT. Dalam siswa mengajar sudah lebih baik dari siklus I. Siswa lebih memahami dan mengerti pada saat proses pembelajaran dilaksanakan. Siswa lebih meningkat dalam hasil pembelajaran dengan menggunakan model pembelajaran kooperatif tipe TGT.Dari hasil postes siswa siklus II maka hasil belajar siswa dapat dilihat pada gambar 3 


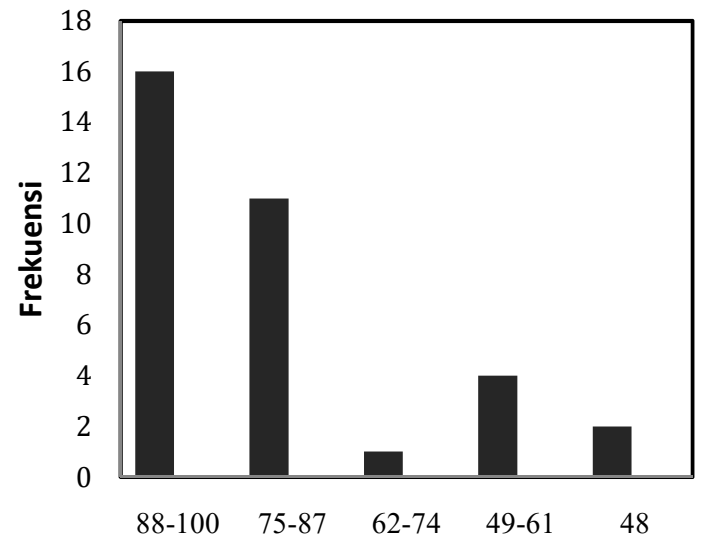

Gambar 3. Hasil Belajar IPA Siklus II

Gambar 3 rata-rata nila siswa pada siklus I 65,30 pada siklus II meningkat menjadi 75,1 jumlah siswa yang mencapai KKM meningkat menjadi 27 , yang belum tuntas berjumlah 7 siswa.Berdasarkan hasil angket kerjasama siswa pada siklus I rata-rata kerjasama siswa mencapai $75,08 \%$ dan mengalami peningkatan menjadi $81,14 \%$ pada siklus II. Berikut hasil analisis kerjasama siswa siklus II.

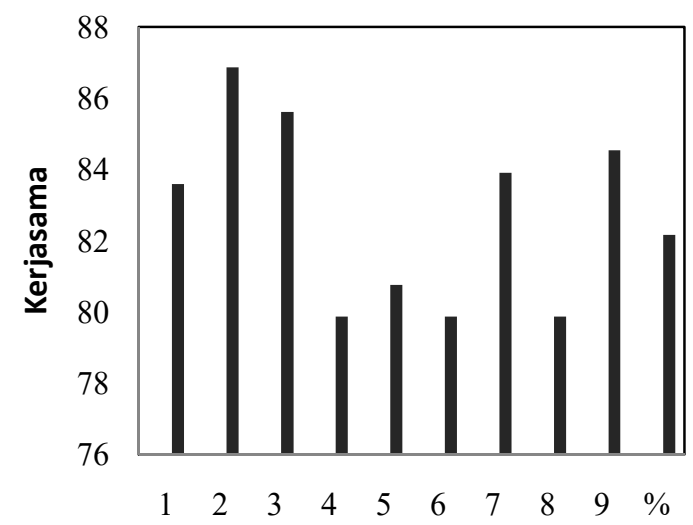

Gambar 4. Persentase Angket Kerjasama Siswa Siklus II. Keterangan Gambar 4 adalah 1) Mengikuti aturan, (2) Membantu teman yang mengalami kesulitan, (3) Ingin semua teman bermain dan berhasil, (4) Memotivasi orang lain, (5) Berpartisipasi dalam menyelesaikan games, (6) Mengendalikan tempramen, (7) Menghargai hak orang lain, (8) Kerjasama meraih tujuan, (9) Menerima pendapat orang lain.

Gambar 4 di atas diperoleh persentase kerjasama siswa siklus II pada semua indikator tekun menghadapi tugas, ulet menghadapi kesulitan, menunjukkan kerjasama, lebih senang bekerjasama, cepat bosan pada tugas rutin, dapat mempertahankan pendapat, tidak mudah melepas hal yang diyakini itu, senang mencari dan memecahkan masalah soal-soalsudah meningkat baik. Pada siklus II kerjasama siswa dengan menggunkan model pembelajaran kooperatif tipe TGT sudah meningkat.

Setelah pembelajaran yang dilakukan pada siklus II berakhir, peneliti melakukan refleksi dengan mengkaji ulang data-data yang diperoleh selama pembelajaran berlangsung. Berdasarkan evaluasi pelaksanaan tindakan dan hasil observasi siklus II disimpulkan bahwa pembelajaran IPA menggunakan model pembelajaran kooperatif tipe TGT sudah cukup berjalan sesuai dengan prosedur yang telah direncanakan dan berjalan lebih baik dibandingkan pada siklus I. Dari hasil angket kerjasama siswa pada siklus 1 adalah sebesar $75,08 \%$ dan mengalami peningkatan pada siklus II menjadi 81,14\%. Hasil belajar IPA siswa mengalami peningkatan pada siklus II. Rata-rata nilai siswa pada siklus I adalah 65,30 meningkat menjadi 75,1 pada siklus II. Pada kekurangankekurangan yang dihadapi pada siklus I dapat diperbaiki pada siklus II.Pada akhir siklus II diputuskan bahwa peneliti tidak melanjutkan siklus penelitian karena indikator keberhasilan penelitian ini telah tercapai.

Berdasarkan data hasil observasi guru dan siswa telah menjalankan langkah-langkah pembelajaranTGT meliputi pembentukan kelompok, pemberian informasi TGT, membuat kesepakatan peraturan, melakukan turnamen dengan kelompok baru, dan penentuan kelompok pemenang pada tiap siklus.

Peningkatan partisipasi siswa dapat teramati oleh peneliti dan kolaborator/observer dari pelaksanaan TGT pada tiap siklus. Perolehan skor/kartu dan atau memenangkan permainan memotivasi para pemain untuk meningkatkan permainan siswa. Sekali siswa memulai permainan, siswa tidak mau berhenti sebelum permainan selesai. Siswa mampu meneruskan tugas yang menjadi tanggung jawabnya di meja turnamen sehingga dapat berkontribusi bagi kelompok asal. Siswa menyelesaikan sesuai dengan waktu yang ditentukan dengan lebih teliti dan lebih baik. Hal ini menunjukkan adanya kerjasama yang berasal dari rasa tertantang, keingintahuan, ingin mendapatkan/ menguasai, ingin berkontribusi/bermanfaat dan impian/harapan. Tampak keaktifan siswa pada meja turnamen seperti aktif mendengarkan, respek/penghargaan/simpati dan berpikir bijaksana, berkomunikasi efektif, dan merasa dipercaya. Selain itu, keterampilan kooperatif atau partisipasi siswa juga telah tampak ketika terjadinya kesepakatan peraturan TGT. Hal tersebut berarti siswa dapat belajar bertanggung jawab untuk memiliki kesamaan pendapat, memahami peranan aturan dalam permainan, belajar untuk dapat menyatakan pendapat dengan cara yang sopan dan sikap yang baik, serta menghargai dan menghormati perbedaan pendapat.Penerapan model 
pembelajaran kooperatif siswa harus bertanggung jawab menguasai materi dan setiap anggota kelompok akan kerjasama untuk menguasai materi sehingga mendorong siswa untuk dapat menguasai materi agar dapat bersaing pada turnamen akademik. Hal ini sesuai dengan teori pembelajaran kooperatif tipe TGT dimana siswa bekerja dalam kelompok kooperatif untuk menguasai materi dan terjadinya kompetisi untuk mendapatkan hasil yang maksimal [16]

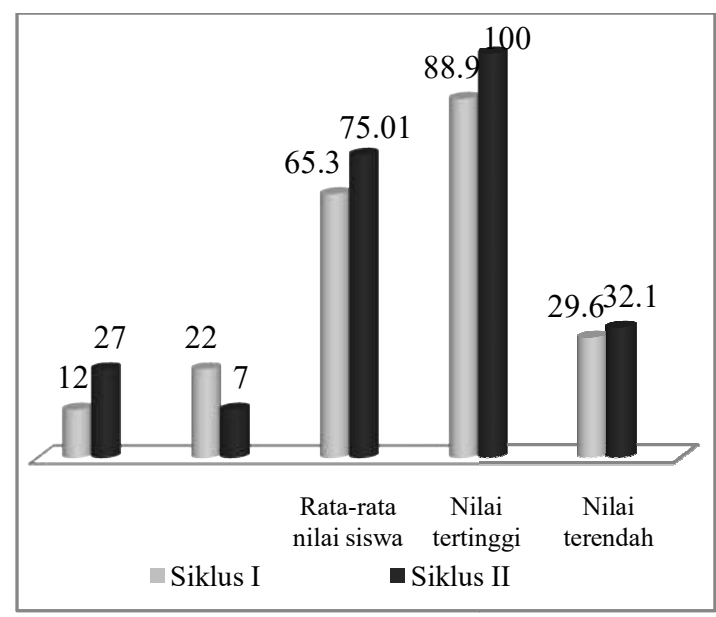

Gambar 5. Diagram Perbandingan Hasil Belajar IPA siklus I dan siklus II

Penggunaan belajar secara kompetitif dalam suasana yang konstruktif memberikan siswa peraturan dan strategi untuk bersaing sebagai individu. Siswa membangun ketergantungan dan kepercayaan dalam tim asal siswa sehingga siswa merasa percaya diri dalam bersaing di meja turnamen. Hal tersebut menunjukkan bahwa siswa telah belajar untuk bersedia memikul tanggung jawab dan tugas-tugas/kewajiban untuk diri sendiri dan kelompok untuk menyelesaikan tugas yang diberikan.Selain itu, siswa menjadi merasa tertantang ketika melihat temannya mampu menjawab dengan benar dan berhasil membawa kartu.Semangat bersaing dengan sportif telah tampak pada tiap meja turnamen. Siswa juga belajar untuk membandingkan jawaban dan memastikan bahwa jawaban itu benar bersama anggota meja turnamen yang lain. Hal ini menunjukkan siswa menjadi semakin berkembang pemahamannya terhadap bidang studi itu serta pada meja turnamen telah berkembang hubungan yang positif antar anggota kelompoknya.

Struktur dan aturan permainan menentukan warna dan membantu sikap positif siswa. Pada penentuan pemenang, tampak siswa dengan prestasi akademik rendah yang membawa lebih banyak kartu dan siswa dengan hasil belajar IPA siswa tinggi yang tidak dapat membawa kartu. Hal tersebut melatih siswa dengan hasil belajar IPA siswa tinggi untuk dapat bergembira melihat orang lain bahagia dan tidak mudah untuk meremehkan siswa dengan hasil belajar IPA siswa rendah. Selain itu, untuk siswa hasil belajar IPA rendah akan lebih termotivasi dalam belajar karena merasa dirinya mampu berbuat lebih baik lagi.

Pembelajaran melalui implementasi model pembelajaran kooperatif tipe TGT ternyata dapat meningkatkan pemahaman konsep siswa pada mata pelajaran IPA. Peningkatan tes siswa yang dilakukan setelah tindakan. Hasil posttes hasil belajar tiap siklus dengan menggunakan model pembelajaran TGT dapat dilihat pada Gambar 5.

Gambar 5 menunjukkan bahwa presentase siswa yang memenuhi KKM meningkat. Presentase siswa yang memenuhi KKM pada pra siklus adalah sebesar 8 siswa. Pada siklus I persentase siswa yang memenuhi KKM meningkat menjadi 12 siswa. Pada siklus II persentase siswa yang memenuhi KKM menjadi 27 siswa. Untuk siswa yang tidak tuntas ada7 karena nilainya belum memenuhi KKM, hal tersebut disebabkan oleh kemampuan belajar yang sedikit lambat dibandingkan siswa yang lain, meskipun demikian ketujuh siswa tersebut pada proses pembelajaran dengan menggunakan model kooperatif tipe team games tournament sudah mengalami peningkatan dalam setiap prosesnya. Peningkatan hasil belajar siswa menunjukkan bahwa semua indikator keberhasilan tindakaan sudah tercapai. Jadi dapat disimpulkan pembelajaran model kooperatif tipe team games tournamentdapat meningkatkan hasil belajar siswa pada mata pelajaran IPA. Hasil penelitian ini sesuai dengan hasil beberapa penelitian sebelumnya, salah satunya penelitian yang telah dilakukan oleh Van Wyk [17] menyatakan bahwa model pembelajaran TGT memberikan hasil positif untuk perbaikan sikap siswa dalam pembelajaran.

Dari hasil belajar siswa pada siklus 1 sebesar 65,30 meningkat menjadi 75,01 pada siklus II. Perbandingan hasil belajar sis ]wa mata pelajaran IPA pada siklus I dan siklus II mengalami peningkatan. Indikator kerjasama yang diamati terdiri dari 9 aspek yaitu mengikuti aturan, membantu teman yang mengalami kesulitan, ingin semua teman bermain dan berhasil, memotivasi orang lain, berpartisipasi dalam menyelesaikan games,mengendalikan tempramen, menghargai hak orang lain, kerjasama meraih tujuan dan menerima pendapat orang lain. Perbandingan dari prasiklus, siklus I, dan siklus II disajikan pada gambar 6 di bawah ini. 


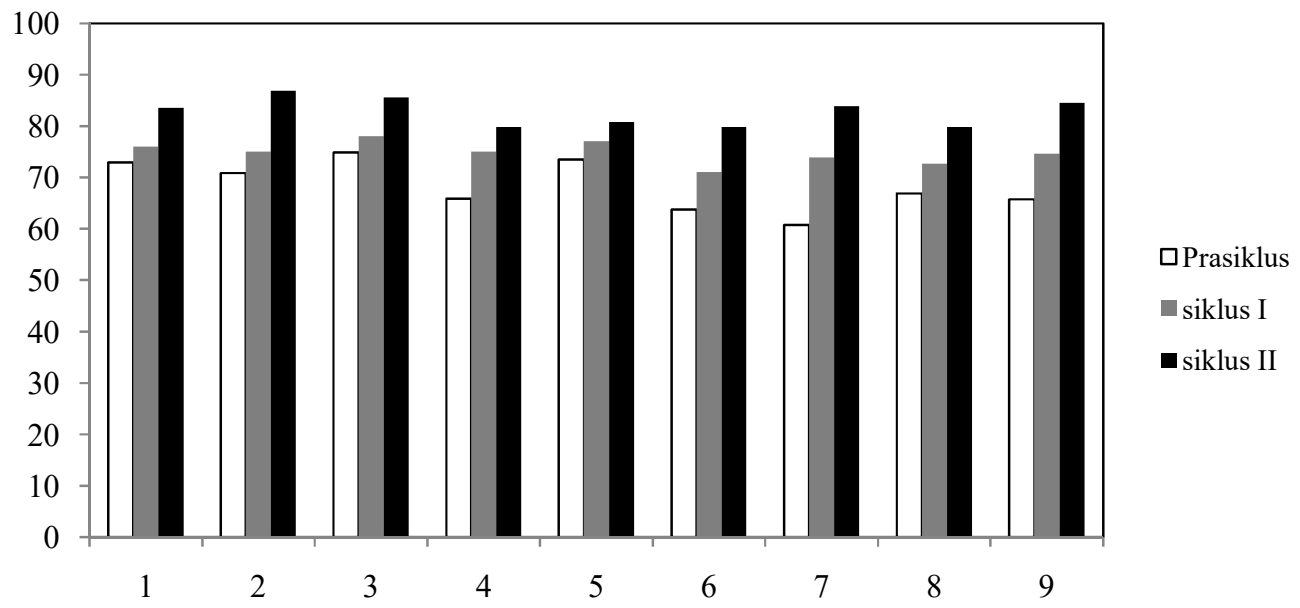

Gambar 6. Perbandingan Kerjasama Siswa Dalam Pembelajaran IPA Pada Siklus I dan Siklus II. Keterangan gambar 6 adalah (1) Mengikuti aturan, (2) Membantu teman yang mengalami kesulitan, (3) Ingin semua teman bermain dan berhasil,(4) Memotivasi orang lain, (5) Berpartisipasi dalam menyelesaikan games, (6) Mengendalikan tempramen, (7) Menghargai hak orang lain, (8) Kerjasama meraih tujuan, (9) Menerima pendapat orang lain.

Gambar 6 menunjukkan bahwa setelah melalui model pembelajaran kooperatif tipe TGT. Kerjasama dan hasil belajar IPA mengalami peningkatan sebesar $15,33 \%$. Hal ini dapat ditunjukkan dengan adanya peningkatan hasil ratarata persentase kerjasama siswa berdasarkan hasil angket untuk tiap siklus, yaitu pada siklus I sebesar $75,08 \%$ meningkat menjadi $82,17 \%$ pada siklus II.

\section{KESIMPULANDAN SARAN}

Berdasarkan analisis data dan pembahasan hasil penelitian dengan melalui model pembelajaran kooperatif tipe TGT pada siswa kelas VIII A SMPN 12 Yogyakarta dapat disimpulkan bahwa proses pelaksanaan pembelajaran melalui model pembelajaran kooperatif tipe TGT dilakukakn dengan beberapa tindakan antara lain: (1) Guru membagi siswa membentuk sebuah kelompok homogen. (2) Guru membagi siswa ke dalam meja-meja turnamen. (3) Guru membagikan kartu soal dan kartu jawaban pada tiap meja-meja turnamen. (4) Guru menjelaskan aturan pertandingan pada tiap meja turnamen. (5) Guru memberikan kesempatan untuk setiap kelompok turnamen untuk melakukan permainan. (6) Guru berkeliling menghampiri atau mengecek jalanannya permainan tiap kelompok. (7) Guru meminta siswa untuk kembali ke kelompok asal. (8)Guru memberikan skor/poin sesuai dengan jumlah kartu soal yang berhasil dijawab. (9) Guru memberikan penghargaan kelompok kepada kelompok yang mendapatkan skor/poin yang tertinggi.

Pembelajaran dengan model pembelajaran kooperatif tipe TGT juga berhasil meningkatkan kerjasama dan hasil belajar IPA siswa kelas VIII A SMP Negeri 12 Yogyakarta. Berdasarkan hasil penelitian menunjukkan bahwa rata-rata persentase kerjasama siswa pada siklus I sebesar 75,08\% meningkat menjadi $82,17 \%$ pada siklus II. Ada peningkatan hasil belajar IPA siswa sebesar 9,28\% rata-rata hasil belajar IPA siswa pada siklus I sebesar $65,30 \%$ meningkat menjadai $75,1 \%$ pada siklus II.Berdasarkan hasil penelitian yang menunjukkan bahwa model pembelajaran kooperatif tipe team games tournament(TGT) dapat meningkatkan kerjasama dan hasil belajar IPA siswa. Peneliti menyarankan kepada guru untuk menerapkan model pembelajaran kooperatif tipe team games tournament(TGT) ini terhadap pembelajaran IPA dengan memperhatikan beberapa hal agar dalam pelaksanaan target dapat dicapai.

\section{DAFTAR PUSTAKA}

[1] Alamsyah, Bunyamin. (2013). Manajemen Mutu Perguruan Tinggi Agama Islam Swasta. Jurnal MP, XXVIII, 2 2013/1434, 203-220.

[2] Handayani, F., (2010), Pembelajaran Kooperatif tipe Team Game Tournamnet (TGT) untuk Meningkatkan Hasil Belajar Siswa Kelas VII SMP Negeri 1 Purwodadi Kabupaten Pasuruan pada Materi Keragaman Bentuk Muka Bumi. Jurnal Penelitian Pendidikan, 2, Oktober 2010

[3] Osviani, R. (2012). Pembelajaran Pytagoras Menggunakan Strategi Relating, Experiencing, Applying, Cooperating, Tranfering (REACT) Di Sekolah Menengah Pertama. Jurnal Edumatica, 2(2),55-56.

[4] Widyastuti, F. (2014). Peningkatan Minat Belajar IPA Melalui Penerapan Strategi 
Word Square Pada Siswa Kelas V SD Negeri Jetis 02 Sukoharjo Tahun 2013/2014. Jurnal Fakultas Keguruan dan Ilmu Pendidikan, 2(1), 45-46

[5] Wijayanti, A. (2016). Implementasi model pembelajaran kooperatif tipe tgt sebagai upaya meningkatkan pemahaman konsep fisika dasar mahasiswa pendidikan IPA. Jurnal Pijar Mipa, 11(1). 15-21.

[6] Yuwono, S. (2016). Meningkatkan Minat dan Hasil Belajar Siswa Melalui Penggunaan Metode Kerja Kelompok Di SD kalilembu Tahun Pelajaran 2015/2016. Jurnal Penelitian Bahasa Indonesia,2(11),34-35.

[7] Safarina, E. I. (2018). Pengaruh Model Pembelajaran Kooperatif Tgt Terhadap Hasil Belajar IPA Ditinjau Dari Kemampuan Kerjasama. Natural: Jurnal Ilmiah Pendidikan IPA, 5(1), 32-37.

[8] Romdhini, M. U., \& Hayati, L. (2009). Upaya Meningkatkan Prestasi Belajar Mahasiswa Pada Pokok Bahasan Integral Melalui Pembelajaran Kooperatif Tipe Team Games Tournament (TGT) Pada Program Studi Pendidikan Matematika FKIP Universitas Mataram. Jurnal Pijar Mipa, 4(2).

[9] Ismah, Z., \& Ernawati, T. (2018). Pengaruh Model Pembelajaran Kooperatif Tipe Teams Games Tournament (TGT) Terhadap Hasil Belajar Ipa Siswa Kelas VIII SMP Ditinjau Dari Kerjasama Siswa. Jurnal Pijar Mipa, 13(1), 82-85.

[10] Yulianti, R., Muntari, M., \& Haris, M. (2015). Pengaruh model pembelajaran kooperatif tipe two stay two stray (TSTS) dengan pendekatan brain-based learning terhadap hasil belajar kimia materi pokok struktur atom dan sistem periodik unsur pada siswa kelas $\mathrm{x}$ sman 1 kediri. Jurnal pijar MIPA, 10(1).

[11] Aryana, I. G. M. R., Al Idrus, A., \& Harjono, A. (2015). Pengaruh model pembelajaran kooperatif NHT dan stad terhadap hasil belajar sikap siswa SMA Negeri 2 Gerung. Jurnal pijar MIPA, 10(2).

[12] Hardini dan Puspitasari. (2012). Strategi Pembelajaran Terpadu. Yogyakarta: Familia.

[13] Sudjana, Nana. (2008). Strategi Pembelajaran. Bandung: Falah Production

[14] Majid, Abdul. (2013). Perencanaan Pembelajaran Mengembangkan Standar Kompetensi Guru.Bandung: PT Remaja Rosdakarya.

[15] Slavin, Robert. (2005). Cooperative Learning. Bandung: Nusa Media.

[16] Respati, A. D. (2013). Penerapan model pembelajaran kooperatif tipe TGT untuk meningkatkan prestasi belajar akuntansi. Jurnal Penelitian UNS. 1 (2), 1-10.

[17] Huda, Miftahul. (2011). Cooperative Learning. Yogyakarta: Pustaka Pelajar.

[18] Najemi, C. (2014) Upaya Peningkatan Minat dan Prestasi Belajar IPA Siswa Kelas VII SMP Negeri 12 Tahun Pelajaran 2012/2013.Jurnal Fakultas Keguruan dan Ilmu Pendidikan.Jurnal Natural,11(1), 1-8.

[19] Arikunto, Suharsimi. (2010). Prosedur Penelitian: Suatu Pendekatan Praktik. Jakarta: Rineka Aksara.

[20] Pratiwi, Y.I. (2014). Pengembangan Media Pembelajaran IPA Terpadu Interaktif Dalam Bentuk Moodle Untuk Siswa SMP Pada Tema Matahari Sebagai Sumber energi Alternatif. Jurnal Pendidikan Fisika, 2(1), 26-27.

[21] Wisnu, D. Y. (2014). Model Pembelajaran TGT untuk meningkatkan Hasil Belajar Siswa SMK. Journal of Mechanical Engineering Education, 1, 2.

[22] Van Wyk, M.M..(2011), The Effects of Teams Games Turnament on Achievement, Retention, and Attitudes of Economics Education Students. Jurnal social Science, 26(3):183-193(2011). 